\title{
Improving Environmental Awareness of High School Students' in Malang City through Earthcomm Learning in the Geography Class
}

\author{
Muhammad Aliman \\ Postgraduate student, Geography Education Program, State University of Malang, \\ Indonesia, muhammad.aliman.1607219@students.um.ac.id \\ Budijanto \\ Prof., Departement of Geography, State University of Malang, Indonesia, \\ budijanto.fis@um.ac.id

\section{Sumarmi} \\ Prof., Departement of Geography, State University of Malang, Indonesia, \\ sumarmi.fis@um.ac.id

\section{Komang Astina} \\ Ph.D., Departement of Geography, State University of Malang, Indonesia, \\ komang.astina.fis@um.ac.id
}

This study aimed to determine the effect of the earthcomm learning model in increasing environmental awareness in high school students. Increased environmental awareness is a representation of students' knowledge, attitudes, behaviors and skills in solving environmental problems. In addition, this study was conducted to know the differences in student activities between classes using the earthcomm learning model and conventional learning models. The study used quasi-experimental design. The data was taken using an instrument of environmental awareness at the pretest and posttest in the experimental and control classes involving high school students in Malang City, Indonesia. Data were analyzed using ANCOVA with SPSS version 23 software for Windows. The results of the study prove that the earthcomm learning model has a significant influence on changes of knowledge, attitudes, behaviors and skills in solving environmental problems in high school students. Students' activity in the experimental class was more active than the control class.

Keywords: earthcomm learning model, environmental awareness, geography learning, high school students, geography class

Citation: Aliman, M. Budijanto, Sumarmi, \& Astina, I. K. (2019). Improving Environmental Awareness of High School Students' in Malang City through Earthcomm Learning in the Geography Class. International Journal of Instruction, 12(4), 79-94. https://doi.org/10.29333/iji.2019.1246a 


\section{INTRODUCTION}

An important problem that often occurs in developing countries like Indonesia is environmental problems. These environmental problems are related to factory activities and motor vehicles that produce air pollution, exploitation of natural resources that do not pay attention to the principle of sustainable development and the amount of waste that is difficult to process (Rathee \& Thakran, 2017), environmental pollution accompanied by deforestation and drought (Cruz et al., 2014). Environmental problems are a difficult part of the government to solve (Soni, Patil, \& Argade, 2016). This is due to the lack of public awareness in protecting the environment (Desa, Abd Kadir, \& Yusooff, 2012) and 20.5\% of high school students in the Hoshiapur District have also low environmental awareness (Kaur, 2017). Various programs from the government are often hampered by the attitudes and behavior of people who do not support the program. In fact, the community is unable to resolve the problems that arise when the program has been fully transferred to the community.

Efforts are needed to foster community attitudes and behavior, especially school students. Environmental attitudes and behaviors can be developed if driven by feelings that are already related to the environment (Nazarenko \& Kolesnik, 2018). Good coaching is guidance given since early beginning, has sustainability and is the key to success in shaping attitudes and behavior towards the environment (Pandey, 2014; Phan Hoang \& Kato, 2016). When attitudes and behaviors of care for the environment based on knowledge have been fostered, awareness will be formed in maintaining an environment sustainably (Mullenbach \& Green, 2018).

Fostering environmental awareness for students can be done through formal education and informal education. Formal education has a system and binding rules such as schools while informal education is education that is tailored to a certain space and time by using technology without strong ties (Jurkovič, 2019). In formal education, various types of learning models can be applied so that learning objectives are easily achieved. Applying a learning model that is in accordance with the conditions of students can increase students' academic knowledge (Yusnaeni, Corebima, Susilo, \& Zubaidah, 2017). The earthcomm learning model is one learning model that is able to engage students and teachers directly with the real conditions of the environment (Keeler \& Mahootian, 1995). Engaging students in conducting inquiry learning in the field can shape their environmental awareness (Al-Balushi \& Al-Aamri, 2014).

Environmental awareness develops when followed by attitudes and behaviors in protecting the environment while knowledge is needed to manage the environment. The attitude of caring for the environment can affect a person's behavior towards the environment; this is due to the level of knowledge (Meinhold \& Malkus, 2005). There are relations between the three indicators, but environmental awareness also requires skills in solving environmental problems (Sengupta, Das, \& Maji, 2010). Many studies have examined environmental awareness indicators separately, such as comparisons of environmental awareness and environmental attitudes (Ajaps \& McLellan, 2015; Anu, 2015; Sengupta et al., 2010), knowledge and attitude to care for the environment (Bradley, Waliczek, \& Zajicek, 1999), environmental awareness in managing solid 
waste in Malaysia (Desa et al., 2012; Soni et al., 2016), in mexico (Cruz et al., 2014), in Ethiopia and USA (Emiru \& Waktola, 2018), in Istanbul Province (Ergen, Baykan, \& Turan, 2015), in the Golaghat District (Ghosh, 2014), Hoshiarpur district (Kaur, 2017), in Ahmedabad District (Pandey, 2014), in Vietnam (Phan Hoang \& Kato, 2016), environmental awareness of renewable energy (Çakirlar Altuntaş \& Turan, 2018), attitudes and behaviors of environmental care (Endut, 2017), but there are not many studies that examine environmental awareness comprehensively. For this reason, research that is able to examine environmental awareness as a whole in terms of knowledge assessment indicators, attitudes, behaviors, and skills in solving environmental problems is needed.

\section{LITERATURE REVIEW}

Learning carried out by teachers and students in the classroom should aim to prepare students to face the 4.0 industrial revolution. The preparation is in the form of thinking skills, work skills, skills in using work tools and survival skills (Chu, Reynolds, Tavares, Notari, \& Lee, 2017). In addition, learning must also be fun and interactive (Utami, Sumarmi, Ruja, \& Utaya, 2016), provide valuable experiences, help the process of creative and critical thinking (Puspitasari, Sumarmi, \& Amirudin, 2016) and improve the ability to solve problems (Woa, Utaya, \& Susilo, 2018).

A learning that involves students inside and outside the room is earth science learning in the community (earthcomm). The advantages of earthcomm learning not only emphasize learning outcomes, but also emphasize the learning process carried out by students. In addition, earthcomm learning aims to: 1) show the relationship of earth science to human life, 2) find solutions to problems experienced by the community, 3) create a broad learning environment for students by involving society, technology and laboratories, 4) foster student awareness towards local, regional and global issues (Carpenter \& Hoover, 2019; Sumarmi, 2015). In addition, earthcomm learning requires a lot of time to do earthcomm learning for geography and geography developed by American national education standards since 2001 (Park, 2001). The stages in earthcomm learning are: 1) scenario, 2) challenge, 3) assessment criteria, 4) goals, 5) think about it, 6) investigate, 7) reflecting on the activity and challenge, 8) digging deeper, 9) check your understanding and applying what you have learned, 10) preparing for the chapter challenge, 11) further inquiry (Park, Yager, \& Smith, 2005).

Students' environmental awareness is not only visible from their knowledge, but also seen from their attitudes, behaviors and skills in solving environmental problems (Desa et al., 2012; Sengupta et al., 2010). Students have knowledge in the form of facts, concepts and relationships to the environment (Fryxell \& Lo, 2003). In addition, student attitudes are a form of evaluative response to objects or circumstances in the form of agreeing or disagreeing (Berkowitz \& Bier, 2004). Meanwhile, behavior towards the environment for students is viewed from imitation, manipulation, precision, articulation and naturalization (Krathwohl, 2002). Students' skills in solving environmental problems are measured using indicators including: identifying goals to be achieved and environmental problems, identifying various solutions, being able to choose alternative solutions to problems, and being able to evaluate the effectiveness of those solutions 
(Marzano, 2001). An instrument is made to measure students' environmental awareness based on the indicators of knowledge, attitudes, behaviors and skills.

Interesting learning for students is learning that involves students contextually. Students are involved directly in the learning process to carry out experiments, research, observation, interviews and discussions (Yusnaeni et al., 2017). A caring attitude in solving environmental problems is not enough to just apply conventional learning (Nazarenko \& Kolesnik, 2018). Learning should provide skills for students to easily understand and be able to solve environmental problems. These skills are competencies that can be possessed by students in order to face 21 st century competition.

Many learning models are used to increase students' environmental awareness, among others, learning that integrates character values and critical thinking in geography learning (Puspitasari et al., 2016), service learning models towards environmental care attitudes (Kasi, Sumarmi, \& Astina, 2018), the project based learning model of student attitudes and behavior (Risnani, Sumarmi, \& Astina, 2017), utilizes the value of local wisdom as a learning resource to develop environmental awareness (Sumarmi, 2016), field trip models that improve environmental attitudes and behavior (Alon \& Tal, 2017) and a problem based learning model for environmental care (Kuvac \& Koc, 2018). Based on the various kinds of learning models application to increase environmental awareness, none of researchers have applied the earthcomm learning model with an emphasis on the process that students go through. Therefore, this study examined the application of the earthcomm learning model in improving knowledge, attitudes, behaviors and skills to solve environmental problems in high school students. The results of the study were expected to know in detail the level of environmental awareness of high school students in terms of knowledge indicators, attitudes, behaviors and skills in solving environmental problems.

\section{METHOD}

The quasi-experimental research was used in the study using the pretest and posttest design with the non equivalent control group. This study aimed to examine the effect of applying earthcomm learning and conventional learning in increasing environmental awareness of high school students. In the initial stage, this study determined the experimental class and the control class, then pretested at the beginning of the meeting using an environmental awareness instrument. The second stage was applying earthcomm learning to the experimental class and applying conventional learning to the control class for 6 weeks. The third stage was conducting the final evaluation (postest) with the same test questions. The last stage was analyzing pretest data and post-data using ANCOVA analysis with SPSS version 23 application for Windows (Wilcox, 2017). Meanwhile, the covariate variable is environmental awareness with subvariables: knowledge, attitudes, behaviors, and student skills in solving environmental problems. The design of environmental awareness instruments on sub-variables of knowledge was measured through indicators: factual, conspetual and procedural. Sub attitude variables were measured using indicators: accept, respond, appreciate and organize characteristics according to values. Sub behavioral variables were measured using indicators: imitation, manipulation, precision, articulation and naturalization. Sub variables of environmental problem resolution skills were measured using indicators: 
identifying objectives, identifying problems, determining problems that were in accordance with the objectives, identifying solutions, choosing the right solutions and evaluating the effectiveness of selected solutions. From the indicators contained in the sub-variables, a list of questions is made to measure these indicators.

\section{Sample}

The location of the study was conducted in Malang City, East Java Province, Indonesia. The research subjects were class X (tenth grade) students majoring in social sciences at Senior High School 5 Malang in the academic year 2017/2018. The study sample was selected from the subject. Based on the research design using the experimental class and the control class, two types of classes were chosen from the three classes. The two types of classes are the experimental class that uses earthcomm learning and the control class that uses conventional learning. The selection of research classes is based on the consideration of the average grade of the previous semester exam which is almost the same. The experimental class chosen was X IIS 1, which consisted of the 30 students who got the average value of 91 and the control class chosen was X IIS 3 that consisted of 27 students who got the average value of 89 .

\section{Instrument}

At the initial meeting, the 57 students were given a pretest using environmental awareness instruments. The instrument used to perform the pretest was first conducted a content test and a construct test by geography learning experts. Moreover, the empirical test was done by testing the instrument to students in other schools as many as 75 students. The empirical test results were analyzed to determine the level of validity and reliability of the instrument toward valid and consistent instrument test results. All of the 42 valid and consistent items were feasible to use at the pretest and posttest. The environmental awareness instrument consisted of knowledge indicators totaling 5 essayshaped questions with Cronbach's alpha score of 0.694, attitude indicators totaling 22 questions in the form of a closed questionnaire with Cronbach's alpha score 0.749 , behavioral indicators totaling 10 questions in the form of a closed questionnaire with Cronbach's alpha score of 0.648 , and environment problem solving skills indicators totaling 5 structured essay questions with Cronbach Alpha 0.893. The results of the pretest were used to determine the knowledge, attitudes, behaviors and skills in solving environmental problems before earthcomm learning was carried out. The final test (posttest) was conducted at the sixth week meeting with the same instrument to measure students' environmental awareness.

\section{Implementation}

The application of the earthcomm learning model was carried out in class X IIS 1 as an experimental class while the application of conventional learning models was conducted on class X IIS 3 as a control class. Students were taught to conduct an investigation of the components that make up the earth system. Students needed creativity to carry out scientific investigations based on challenges and problems given by the teacher. The stages in the earthcomm learning model included: The teacher designed the initial scenario of challenges for students, students explore the challenges given by the teacher to design solutions for the earth system problems, the teacher provided criteria for the 
assessment process to students, students understood the steps of inquiry to find solutions, students conducted field investigations by reflecting on the results of temporary data, students and teachers conducted in-depth studies by correlating secondary data and literature, students present the results of investigations, students and teachers review weaknesses and strengths from the results of investigations to be completed in further investigation, and students conduct further investigations to search the solution to a different problem.

The stages of the earthcomm learning model emphasized the learning process carried out by students including the final assessment criteria for learning outcomes. Therefore, the application of the earthcomm model required the teacher's ability to control the activities of students before and after learning (investigation outside or in the classroom). Research carried out was adjusted to the Indonesian national curriculum on basic knowledge competencies 3.7 that is analyzing the dynamics of the hydrosphere and its impact on life and basic skills competencies 4.7 , namely presenting the process of hydrosphere dynamics using maps, charts, images, tables, graphs, videos and or animations.

Basic competencies 3.7 and 4.7 in class $\mathrm{X}$ contain material components of the earth system in the form of water cycles, phenomena and their impact on humans. In this material, students were given an explanation of the water phenomenon and the positive and negative effects of its existence. The teacher invited students to examine the problems posed by water, one of the problems encountered by students of class X IIS 1 was to find problems with decreasing water quality in the upstream part of the Brantas watershed in Malang City, East Java Province. To prove the decline in water quality, students of class X IIS 1 conducted an investigation of water quality in three locations in the upstream part of the Brantas watershed as seen in the following figure 1.

The investigation was conducted by collecting physical data on water quality and environmental social data around the location of the investigation. Physical data on water quality were measurements of water discharge, temperature, color, and mineral content dissolved in water, while social data were population demographic data, household waste management and river water utilization by residents. The data obtained was then collected, described and sought for its correlation by conducting discussions with the teacher. The final results of the report were then presented in front of the class so that there was a correlation between the quality of water in each location and the activities of the population around the location of the investigation.

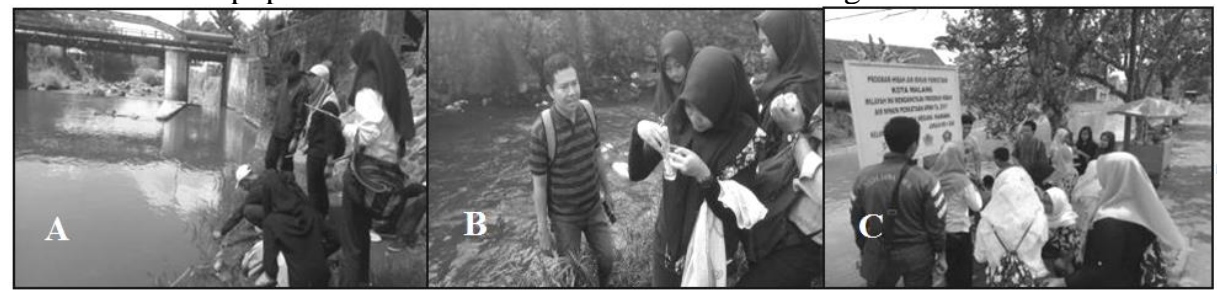

a. Location $1: 7^{0} .54^{\prime} 48.25^{\prime}$ 'S, b. Location $2: 7^{0} .59^{\prime} 15.86$ ”S, c. Location 3: $8^{0} .00^{\prime} 37.62^{\prime \prime S}$ Picture 1

Location of Water Quality Investigation of the Upstream Brantas River 


\section{Data Analysis}

The pretest and posttest results of the six research classes were analyzed using statistical tests. The data analyzed were the pretest value, posttest value and gain score from the six research groups. The analysis prerequisites of the data collected were tested by using the Kolmogorov-Smirnov and the Shapiro-Wilk tests for the normality test while the Levene's test for homogeneity test. In addition, the ANCOVA was used in testing the hypothesis to find out whether there is an effect of implementing the earthcomm learning model on environmental awareness of students, which consisted of two initial hypothesizes, accepted or rejected. All of these analyses used SPSS software version 23.0 for Windows.

\section{FINDINGS AND DISCUSSION}

Research in the experimental class and control class was conducted to see changes in environmental awareness using the pretest and posttest. Preliminary data processing was done to test the normality and homogeneity of data in a significance level of 0.05 . Prior to the data analysis, the normality test using Kolmogorov-Smirnov and Shapiro-Wilk were performed. The results of the data analysis show that data are normally distributed $(\mathrm{p}=>0.05)$ as in the table 1 while the homogeneity test using Levene test show that the data are homogenous $(\mathrm{p}=0,142>0.05)$ as in the table 2 .

Table 1

Normality Test

\begin{tabular}{llllllll}
\hline & Research & \multicolumn{6}{l}{ Kolmogorov-Smirnov $^{\mathrm{a}}$} \\
\cline { 3 - 7 } & Class & Statistic & $d f$ & $p$ & Shapiro-Wilk & \\
\hline \multirow{2}{*}{ Result } & Pretest Exp & .083 & 30 & $.200^{*}$ & .969 & 30 & .521 \\
Environmental & Postest Exp & .091 & 30 & $.200^{*}$ & .934 & 30 & .063 \\
Awareness & Pretest Con & .110 & 27 & $.200^{*}$ & .970 & 27 & .591 \\
& Postest Con & .145 & 27 & .154 & .928 & 27 & .062 \\
\hline
\end{tabular}

Table 2

Homogeneity Test

\begin{tabular}{llll}
\hline \multicolumn{4}{c}{ Environmental Awareness } \\
\hline Levene Statistic & $d f 1$ & $d f 2$ & $p$ \\
\hline 2.220 & 1 & 55 & .142 \\
\hline
\end{tabular}

The results of the normality test and data homogeneity test were proved to be significant so the data could be tested using ANCOVA test to see the effect of the learning model on each indicator of environmental awareness. The following are the average results of the pretest and posttest for each indicator of environmental awareness. 
Table 3

Pretest and Posttest Results of Experiment and Control Classes

\begin{tabular}{|c|c|c|c|c|c|}
\hline \multirow{2}{*}{$\begin{array}{l}\text { Environmental } \\
\text { Awareness Indicators }\end{array}$} & \multirow{2}{*}{ Group } & \multirow{2}{*}{ Pretest } & \multirow{2}{*}{ Postest } & \multicolumn{2}{|c|}{ Improvement } \\
\hline & & & & Score & $\%$ \\
\hline \multirow{2}{*}{ Knowledge } & Experiment & 8,73 & 19,03 & 10,3 & 117,98 \\
\hline & Control & 8,52 & 17,93 & 9,41 & 110,45 \\
\hline \multirow{2}{*}{ Attitude } & Experiment & 70,27 & 84 & 13,73 & 19,54 \\
\hline & Control & 68,22 & 75,78 & 7,56 & 11,08 \\
\hline \multirow{2}{*}{ Behavior } & Experiment & 30,07 & 37,33 & 7,26 & 24,14 \\
\hline & Control & 29,04 & 33,59 & 4,55 & 15,67 \\
\hline \multirow{2}{*}{ Skills } & Experiment & 11,53 & 19,23 & 7,7 & 66,78 \\
\hline & Control & 7,74 & 16,22 & 8,48 & 109,56 \\
\hline
\end{tabular}

Table 3 explains that the two research classes experienced an increase in the four indicators in terms of the average pretest and posttest. There is a significant increase in the knowledge indicators in the experimental class and the control class while a nonsignificant increase occurred in attitude and behavior indicators in the experimental and control classes. In general, the experimental class has a high environmental awareness value compared to the control class. However, there is a unique thing that the skill indicator in the control class experienced a significant increase compared to the experimental class. The motor skills of control class students that are more enthusiastic in solving environmental problems than the experimental class are assumed as the reason of this condition occured. Based on table 3, the level of environmental awareness of the two research classes is at the level of reflected environmental awareness. The changes in environmental awareness can be seen in graph 1 .

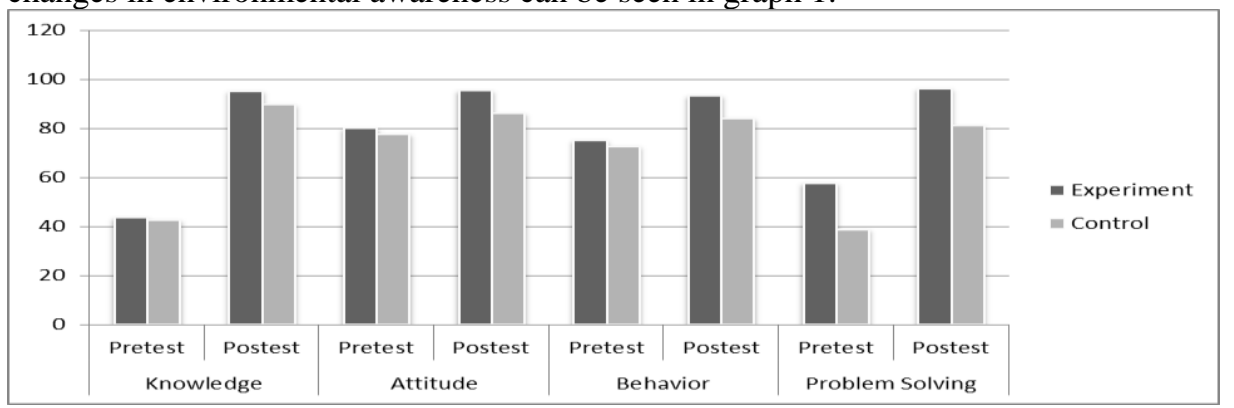

Figure 1

Changes in Environmental Awareness of High School Students

Increased posttest results in the experimental class were caused by the application of the earthcomm learning model which stimulated students to find solutions by conducting investigations in the field. The application of this model can function to increase student environmental awareness if the teacher is able to understand the steps of learning and teach students well (Valderrama-Hernández, Alcántara, \& Limón, 2017). Teacher participation is needed in implementing environment-based learning (Nazarenko \& Kolesnik, 2018). 


\section{Environmental Knowledge}

The first indicator of assessment in this study is environmental knowledge that reveals students' cognitive abilities regarding environmental management related to watershed conditions. It can be seen in table 4 for more details.

Table 4

ANCOVA Test Results for Environmental Knowledge

\begin{tabular}{lllll}
\hline Source & $d f$ & $M S$ & $F$ & $p$ \\
\hline Corrected Model & 2 & 9.173 & 3.998 & .024 \\
Intercept & 1 & 913.245 & 398.026 & .000 \\
Pretest & 1 & .919 & .401 & .529 \\
Group & 1 & 16.945 & 7.385 & .009 \\
Error & 54 & 2.294 & & \\
Total & 57 & & & \\
Corrected Total & 56 & & & \\
\hline
\end{tabular}

$\mathrm{R}$ Squared $=.129$ (Adjusted R Squared $=.097$ )

Based on the table of results of environmental knowledge covariates of Senior High School 5 Malang students, it can be explained that the value of $\mathrm{F}=0.401$ with a significance level of 0.529 ( $p>0.05$ ) indicates that there is no significant effect on students' environmental knowledge. Moreover, the effect of applying the earthcomm learning model to students' environmental knowledge has significant results because based on the effect test, the value of $F=7.385$ with a significance level of 0.009 ( $p>$ 0.05). Therefore, the earthcomm learning model is proven to be able to increase students' knowledge in managing the environment.

The results of data processing in table 4 also support the opinion that explains that the application of learning models that are in accordance with the conditions of students can develop students 'cognitive abilities, including in the category of students' low academic ability (Yusnaeni et al., 2017). One of the objectives of earthcomm learning developed by the American national education standard is to improve learning outcomes including students' cognitive abilities (Park \& Park, 2013). In earthcomm learning, students are involved directly in conducting investigations in the field, so the concept of knowledge acquired in the classroom is strengthened by the facts in the field. This study also supports other studies which state that environmental education training can develop students' knowledge of waste management and the environment (Nazarenko \& Kolesnik, 2018; Phan Hoang \& Kato, 2016). The same study also states that between knowledge and caring attitudes of renewable energy sources has a strong correlation on 600 high school students in Turkey (Çakirlar Altuntaş \& Turan, 2018). Furthermore, the survey conducted on 430 respondents in Malaysia stated that the public knew various environmental problems but participation in managing the environment was relatively low (Kamaruddin, Ahmad, \& Alwee, 2016).

\section{Environmental Attitudes}

The second assessment of environmental awareness is an indicator of environmental attitudes. The attitudes in question were a student's perception that involves his feelings and emotions towards the condition of the watershed. It can be seen in table 5 for more details. 
Table 5

ANCOVA Test Results for Environmental Attitudes

\begin{tabular}{lllll}
\hline Source & $d f$ & $M S$ & $F$ & $p$ \\
\hline Corrected Model & 2 & 547.657 & 36.598 & .000 \\
Intercept & 1 & 1490.936 & 99.635 & .000 \\
Pretest & 1 & 134.612 & 8.996 & .004 \\
Group & 1 & 812.545 & 54.300 & .000 \\
Error & 54 & 14.964 & & \\
Total & 57 & & & \\
Corrected Total & 56 & & & \\
\hline \multicolumn{2}{r}{ R Squared $=.575$ (Adjusted R Squared $=.560)$} &
\end{tabular}

Based on table 5 of the environmental attitude covariate results of Senior High School 5 Malang students, it can be explained that the value of $F=8.996$ with a significance level of $0.004(p>0.05)$ indicates that there is a significant effect on students' environmental attitudes. Moreover, the effect of applying the earthcomm learning model to students' environmental attitudes has significant results because the value of $\mathrm{F}=54,300$ with a significance level of $0,000(p>0,05)$ based on the effect test. The earthcomm learning model can also increase students' learning motivation (Hidayat, Sarwono, \& Yusup, 2017). Good student motivation in learning can also be proven by their attitudes and behavior. Earthcomm learning that involves students in the field is able to familiarize students to pay attention to environmental issues around them, so that it can foster students' care for the environment.

The results of this study contradict the research that stated environmental behavior was not optimal while knowledge and caring attitudes about climate change and support for global efforts to protect the earth were optimal (Emiru \& Waktola, 2018). This adds to the variety of discourses that between good knowledge and caring attitudes are not necessarily followed by good environmental behavior (Ergen et al., 2015; VicenteMolina et al., 2013). Knowledge should be the initial foundation in forming caring attitudes and behaviors towards the environment (Meinhold \& Malkus, 2005).

\section{Environmental Behavior}

The third assessment of environmental awareness indicators is student behavior in following up on responses and influences on watershed environmental conditions. It can be seen in table 6 for more details.

Table 6

ANCOVA Test Results for Environmental Behavior

\begin{tabular}{lllll}
\hline Source & $d f$ & $M S$ & $F$ & $p$ \\
\hline Corrected Model & 2 & 112.098 & 27.287 & .000 \\
Intercept & 1 & 393.830 & 95.866 & .000 \\
Pretest & 1 & 25.346 & 6.170 & .016 \\
Group & 1 & 167.415 & 40.752 & .000 \\
Error & 54 & 4.108 & & \\
Total & 57 & & & \\
Corrected Total & 56 & & \\
\hline R Squared $=.503$ (Adjusted R Squared $=.484)$ & \\
\hline
\end{tabular}


Based on the table of the environmental behavior covariate results of Senior High School 5 Malang students, it can be explained that the value of $F=6.170$ with a significance level of 0.016 ( $p>0.05$ ) indicates that there are significant changes in students' environmental behavior. Moreover, the effect of applying the earthcomm learning model to students' environmental behavior has significant results because the value of $F=40.752$ with a significance level of $0.000(p>0.05)$ based on the effect test.

This result is different from research that stated that awareness (behavior) does not have a significant relationship to environmental attitudes on students in Golaghat Village (Ghosh, 2014). Spanish students (Vicente-Molina et al., 2013). The conflicting relationship between attitudes and behavior was caused by weak reliability and instrument validity and the influence of other factors such as motivation and measurement that are different from attitude and behavior measurements (Mainieri, Barnett, Valdero, Unipan, \& Oskamp, 1997). The biggest influence of the growth of environmental behavior is motivation. If motivation in doing action is high, the behavior occured is also in accordance with the goal (Kollmuss \& Agyeman, 2002). The different thing was also found in 600 high school students in the Pathanamthitta District, Kerala that behaviors and caring attitudes have a strong relationship (Anu, 2015). Furthermore, this study explains that the application of the earthcomm learning model plays a role in improving attitudes and caring behavior towards the environment.

\section{Skills in Solving Environmental Problems}

Students 'abilities that are assessed on this indicator are students' skills in solving problems caused by environmental changes, especially around the river flow. The results of processing data can be seen in table 7 .

Table 7

ANCOVA Test Results for Environmental Problems Solving Skills

\begin{tabular}{lllll}
\hline Source & $d f$ & $M S$ & $F$ & $p$ \\
\hline Corrected Model & 2 & 74.360 & 21.804 & .000 \\
Intercept & 1 & 785.742 & 230.401 & .000 \\
Pretest & 1 & 19.876 & 5.828 & .019 \\
Group & 1 & 37.849 & 11.098 & .002 \\
Error & 54 & 3.410 & & \\
Total & 57 & & & \\
Corrected Total & 56 & & & \\
\hline R Squared $=.447$ (Adjusted R Squared $=.426)$ & \\
\hline
\end{tabular}

Based on the table of the covariate skills in solving environmental problems results of Senior High School 5 Malang students, it can be explained that the value of $F=5.828$ with a significance level of 0.019 ( $p>0.05)$ indicates that there are significant changes in students' environmental problem-solving skills. Moreover, the effect of applying the earthcomm learning model to students' skills in solving environmental problems has significant results because the value of $F=11.098$ with a significance level of 0.002 ( $p>$ 0.05 ) based on the effect test. The increasing of students' skills in solving environmental problems was caused by earthcomm learning activities that involve students in Digging 
deeper and students were required to complete the challenges given at the beginning of learning.

Students' skills in solving environmental problems, especially the environment around schools, homes and around the river flow can be contributed by the application of the earthcomm learning model. In addition to the application of the earthcomm learning model, environmental education training can attract $96 \%$ of students' interest in reducing waste by recycling plastic waste into useful items (Phan Hoang \& Kato, 2016). However, different research findings were found in the application of the environmental education curriculum at Madara Kamaraj University in Tamil Nadu, which explained that there was no strong relationship between environmental behavior and skills in solving environmental problems (Sivamoorthy, Nalini, \& Kumar, 2013). For this reason, more concrete efforts are needed to increase overall environmental awareness. One of them is by implementing earthcomm learning that is able to increase knowledge, attitudes, behaviors and skills on an ongoing basis.

\section{CONCLUSION}

Based on the discussion of the results of the study, it can be concluded that the average value of research classes that apply the earthcomm learning model has higher knowledge, attitudes, behaviors and skills in solving environmental problems compared to research classes that apply conventional learning models. The earthcomm learning model is able to internalize knowledge and skills to solve environmental problems better than internalizing environmental caring attitudes and behaviors in high school students.

\section{IMPLICATIONS AND RECOMMENDATIONS}

The results of this study have theoretical implications for agreeing that knowledge is the basis of the formation of attitudes and attitudes that can affect human behavior. Moreover, human ability to solve problems is a holistic representation of humans who have good environmental awareness. Practically, this research proves that the application of the earthcomm learning model is effective in increasing students' environmental awareness.

Geography teachers are recommended to use the earthcomm learning model as an effort to internalize knowledge, attitudes, behaviors and skills in solving environmental problems for high school students. In addition, this research can be developed to reveal the effectiveness of the earthcomm learning model compared to other similar learning models and reveal the effectiveness of the earthcomm learning model in improving students' spatial thinking skills and other abilities needed in facing the challenges of the industrial revolution 4.0.

\section{REFERENCES}

Ajaps, S., \& McLellan, R. (2015). We don't know enough: Environmental education and pro-environmental behaviour perceptions. Cogent Education, 2(1), 1-17. https://doi.org/10.1080/2331186X.2015.1124490. 
Al-Balushi, S. M., \& Al-Aamri, S. S. (2014). The effect of environmental science projects on students' environmental knowledge and science attitudes. International Research in Geographical and Environmental Education, 23(3), 213-227. https://doi.org/10.1080/10382046.2014.927167.

Alon, N. L., \& Tal, T. (2017). Field trips to natural environments: How outdoor educators use the physical environment. International Journal of Science Education, Part B, 7(3), 237-252. https://doi.org/10.1080/21548455.2016.1250291.

Anu, S. (2015). A Comparative study on environmental awareness and environmental attitude among secondary school students of Pathanamthitta District in Kerala. Online International Interdisciplinary Research Journal, V(III), 127-131.

Berkowitz, M. W., \& Bier, M. C. (2004). Research-based character education. The Annals of the American Academy of Political and Social Science, 591, 72-85.

Bradley, J. C., Waliczek, T. M., \& Zajicek, J. M. (1999). Relationship between environmental knowledge and environmental attitude of high school students. The J. of Environmental Educ., 30(3), 17-21. https://doi.org/10.1080/00958969909601873.

Çakirlar Altuntaş, E., \& Turan, S. L. (2018). Awareness of secondary school students about renewable energy sources. Renewable Energy, 116, 741-748. https://doi.org/10.1016/j.renene.2017.09.034.

Carpenter, M., \& Hoover, M. (2019). What is earthcomm, second edition? [Html]. Retrieved from EarthComm, Second Edition website: http://www.agiweb.org/education/earthcomm2/about.html.

Chu, S. K. W., Reynolds, R. B., Tavares, N. J., Notari, M., \& Lee, C. W. Y. (2017). Twenty-First century skills and global education roadmaps. In S. K. W. Chu, R. B. Reynolds, N. J. Tavares, M. Notari, \& C. W. Y. Lee (Eds.), 21st century skills development through inquiry-based learning (pp. 17-32). https://doi.org/10.1007/978981-10-2481-8_2.

Cruz, R. A. S., Keleng, L., Balderrama, S., Sanchezverin, C. V., Palma, N. A., Olivas, O. V., \& Duran, A. (2014). Environmental awareness of the young in a rural community in the Sierra Tarahumara, Chihuahua, Mexico. J. of Educ. and Practice, 5(2), 197-201.

Desa, A., Abd Kadir, N. B., \& Yusooff, F. (2012). Environmental Awareness and education: A key approach to solid waste management (SWM) - A case study of a University in Malaysia. In L. F. M. Rebellon (Eds.), Waste management - An integrated vision (pp. 101-112). IntechOpen. https://doi.org/10.5772/48169.

Emiru, T. S., \& Waktola, D. K. (2018). The environmental awareness of higher education students and the implications for the Paris Climate Agreement: empirical evidences from Ethiopia and USA. International Res. in Geogr. and Environmental Education, 27(3), 216-233. https://doi.org/10.1080/10382046.2017.1349375.

Endut, A. (2017). The need of a study on environmental awareness (EA) in the sight of national philosophy of education (NPE) in Malaysia. International Journal of Innovative Research and Knowledge, 2(1), 35-43. 
Ergen, A., Baykan, B. G., \& Turan, S. G. (2015). Effect of materialism and environmental knowledge on environmental consciousness among high school students: A Study conducted in Istanbul Province. International Journal of Human Sciences, 12(1), 511. https://doi.org/10.14687/ijhs.v12i1.3130.

Fryxell, G. E., \& Lo, C. W. (2003). The Influence of environmental knowledge and values on managerial behaviors on behalf of the environment: An empirical examination of managers in China. Journal of Business Ethics, 46(1), 45-69.

Ghosh, K. (2014). Environmental Awareness among secondary school students of golaghat district in the state of assam and their attitude towards environmental education. Journal of Humanities and Social Science, 19(3), 30-34.

Hidayat, A., Sarwono, \& Yusup, Y. (2017). Earthcomm-based multimedia learning of geography in improving learning motivation and spatial ability of the high school students. Proceedings of The International Conference on Teaching Training and Education 2017 (ICTTE 2017). Presented at the Teacher Training and Education: Opportunity and Challenges in Fostering Quality Learning in Open Knowledge, Universitas Sebelas Maret, Surakarta, Central Java, Indonesia. https://doi.org/10.2991/ictte-17.2017.29.

Jurkovič, V. (2019). Online informal learning of English through smartphones in Slovenia. System, 80, 27-37. https://doi.org/10.1016/j.system.2018.10.007.

Kamaruddin, S. M., Ahmad, P., \& Alwee, N. (2016). Community awareness on environmental management through local agenda 21 (LA21). Procedia - Social and Behavioral Sciences, 222, 729-737. https://doi.org/10.1016/j.sbspro.2016.05.234.

Kasi, K., Sumarmi, \& Astina, I. K. (2018). Pengaruh Model Pembelajaran Service Learning terhadap Sikap Peduli Lingkungan [Effect of Service-Learning Learning Model on Environmental Care Attitudes]. Jurnal Pendidikan: Teori, Penelitian, dan Pengembangan, 3(4), 437-440.

Kaur, J. (2017). Environmental awareness among +1 class school students of Hoshiarpur District. IOSR Journal of Humanities and Social Science, 22(07), 07-12. https://doi.org/10.9790/0837-2207020712.

Keeler, M., \& Mahootian, F. (1995). Building the earth system science community. ResearchGate. http://dx.doi.org/10.1109/IGARSS.1995.520459.

Kollmuss, A., \& Agyeman, J. (2002). Mind the gap: Why do people act environmentally and what are the barriers to pro-environmental behavior? Environmental Education Research, 8(3), 239-260. https://doi.org/10.1080/13504620220145401.

Krathwohl, D. R. (2002). A Revision of bloom's taxonomy: An Overview, theory into practice (Vol. 41). Ohio: Colledge of Education, The Ohio State University.

Kuvac, M., \& Koc, I. (2018). The effect of problem-based learning on the environmental attitudes of preservice science teachers. Educational Studies, 45(1), 7294. https://doi.org/10.1080/03055698.2018.1443795. 
Mainieri, T., Barnett, E. G., Valdero, T. R., Unipan, J. B., \& Oskamp, S. (1997). Green buying: The Influence of environmental concern on consumer behavior. The Journal of Social Psychology, 137(2), 189-204. https://doi.org/10.1080/00224549709595430.

Marzano, R. J. (2001). A New taxonomy of education objectives. In A. L. Costa (Eds.), developing minds: A Resource book for teaching thinking (pp. 181-189). Alexandria, VA: Association for Supervision and Curriculum Development.

Meinhold, J. L., \& Malkus, A. J. (2005). Adolescent environmental behaviors: Can knowledge, attitudes, and self-efficacy make a difference? Environment and Behavior, 37(4), 511-532. https://doi.org/10.1177/0013916504269665.

Mullenbach, L. E., \& Green, G. T. (2018). Can environmental education increase student-athletes' environmental behaviors? Environmental Education Research, 24(3), 427-444. https://doi.org/10.1080/13504622.2016.1241218.

Nazarenko, A. V., \& Kolesnik, A. I. (2018). Raising Environmental awareness of future teachers. International J. of Ins., 11(3), 63-76. https://doi.org/10.12973/iji.2018.1135a.

Pandey, P. (2014). Environmental Awareness ability study of higher secondary school students of ahmedabad with context to gender and stream of study. IV(Special), 317323.

Park, D. Y. (2001). A Study of earth system science in the community (Earthcomm) in terms of its congruency with the visions in the national science education standards and its effectiveness student learning (Unpublished doctoral dissertations). The University of Iowa, Iowa.

Park, D. Y., \& Park, M. (2013). Examining the features of earth science logical reasoning and authentic scientific inquiry demonstrated in a high school earth science curriculum: A case study. Journal of Geoscience Education, 61(4), 364-377. https://doi.org/10.5408/12-360.1.

Park, D. Y., Yager, R. W., \& Smith, M. (2005). Implementing earthcomm: Teacher Professional development and its impact on student achievement scores in a standardsbased earth science curriculum. Electronic Journal of Science Education, 9(3). Retrieved from http://ejse.southwestern.edu/article/view/7733.

Phan Hoang, T. T., \& Kato, T. (2016). Measuring the effect of environmental education for sustainable development at elementary schools: A case study in Da Nang city, Vietnam. Sustainable Environment Research, 26(6), 274-286. https://doi.org/10.1016/j.serj.2016.08.005.

Puspitasari, E., Sumarmi, S., \& Amirudin, A. (2016). Integritas Berpikir Kritis Dan Peduli Lingkungan Melalui Pembelajaran Geografi Dalam Membentuk Karakter Peserta Didik SMA [Integrity Critical Thinking and Environmental Care Through Geography Learning in Forming Character High School Students]. Jurnal Pendidikan: Teori, Penelitian, dan Pengembangan, 1(2), 122-126.

Rathee, N., \& Thakran, S. (2017). A Study of environmental awareness among rural and urban secondary school students. International Education and Research, 3(5), 204-205. 
Risnani, R., Sumarmi, S., \& Astina, I. K. (2017). Implementation of project-based learning $(\mathrm{PjBL})$ through One man one tree to improve students' attitude and behavior to $\begin{array}{lllll}\text { support. International Education } & \text { Studies, } & \text { 10(3), } & 134 .\end{array}$ https://doi.org/10.5539/ies.v10n3p134.

Sengupta, M., Das, J., \& Maji, P. K. (2010). Environmental awareness and environment related behaviour of twelfth grade students in Kolkata: Effects of stream and gender. Anwesa, 5, 1-8.

Sivamoorthy, M., Nalini, R., \& Kumar, C. S. (2013). Environmental awareness and practices among college students. Intern. J. of Human. and Soc. Sci. Inv., 2(8), 11-15.

Soni, A., Patil, D., \& Argade, K. (2016). Municipal solid waste management. Procedia Environmental Sciences, 35, 119-126. https://doi.org/10.1016/j.proenv.2016.07.057.

Sumarmi. (2015). Model-model Pembelajaran Geografi [Geography learning models]. Yogyakarta: Aditya Media Publishing.

Sumarmi. (2016). A Study of local wisdom of balinese aga and samin people to develop environmental awareness characteristics. Advances in Social Science, Education and Humanities Research, 79, 201-205.

Utami, W. S., Sumarmi, Ruja, I. N., \& Utaya, S. (2016). React (relating, experiencing, applying, cooperative, transferring) strategy to develop geography skills. Journal of Education and Practice, 7(17), 100-104.

Valderrama-Hernández, R., Alcántara, L., \& Limón, D. (2017). The Complexity of environmental education: teaching ideas and strategies from teachers. Procedia - Social and Behavioral Sciences, 237, 968-974. https://doi.org/10.1016/j.sbspro.2017.02.137.

Vicente-Molina, M. A., Fernández-Sáinz, A., \& Izagirre-Olaizola, J. (2013). Environmental knowledge and other variables affecting pro-environmental behaviour: comparison of university students from emerging and advanced countries. Journal of Cleaner Production, 61, 130-138. https://doi.org/10.1016/j.jclepro.2013.05.015.

Wilcox, R. (2017). Introduction to robust estimation and hypothesis testing. San Diego, United States: Elsevier Science Publishing.

Woa, K. M., Utaya, S., \& Susilo, S. (2018). Pengaruh Model Pembelajaran Problem Based Learning terhadap Kemampuan Memecahkan Masalah Geografi pada Siswa $S M A$ [Effect of problem-based learning model on the ability to solve geographic problems in high school students]. Jurnal Pendidikan: Teori, Penelitian, dan Pengembangan, 3(3), 406-411.

Yusnaeni, Y., Corebima, A. D., Susilo, H., \& Zubaidah, S. (2017). Creative thinking of low academic student undergoing search solve create and share learning integrated with metacognitive strategy. International Journal of Instruction, 10(2), 245-262. https://doi.org/10.12973/iji.2017.10216a. 